\title{
ANALISIS TINDAK TUTUR PADA WAWANCARA PUTRA NABABAN DAN PRESIDEN PORTUGAL (KAJIAN PRAGMATIK)
}

\author{
Syahrizal Akbar \\ Universitas Prima Indonesia (Unpri) Medan \\ Pos-el: akbarsyahrizal@ymail.com
}

\begin{abstract}
This mini research aims to describe the form of speech acts in the locution, ilocution, and perlocution that exist in interviews RCTI journalist, Putra Nababan with the President of Purtugal, Antonio Covaco Silva.

The research method in this research is descriptive qualitaive method. Sources of data from interviews RCTI journalist, Putra Nababan with President of Portugal, Antonio Covaco Silva. In categorizing the data, the researcher uses the techniques of referring, recording, and noting.

Based on data analysis, it was concluded that interview between RCTI journalist, Putra Nababan and President of Portugal, Antonio Covaco Silva has an act of ilocution with assertive, directive, commisive, expressive, and declaration type.
\end{abstract}

Keywords: locution, ilocution, perlocution, pragmatic study

\begin{abstract}
Abstrak
Penelitian mini ini bertujuan untuk mendeskripsikan wujud tindak tutur berupa lokusi, ilokusi, dan perlokusi yang terdapat dalam wawancara wartawan RCTI, Putra Nababan dengan Presiden Portugal, Antonio Cavaco Silva.

Metode penelitian yang digunakan dalam penelitian mini ini adalah metode deskriptif kualitatif. Adapun sumber data diperoleh dari kutipan wawancara antara wartawan RCTI, Putra Nababan dengan Presiden Portugal, Antonio Cavaco Silva. Dalam pengumpulan data, penenliti menggunakan teknik simak, rekam dan catat.

Berdasarkan analisis data, disimpulkan bahwa dalam wawancara wawancara antara wartawan RCTI, Putra Nababan dengan Presiden Portugal, Antonio Cavaco Silva terdapat tindak ilokusi dengan jenis asertif, direktif, komisif, ekspresif, dan deklarasi.

Kata kunci: lokusi, ilokusi, perlokusi, kajian pragmatik.
\end{abstract}

\section{PENDAHULUAN}

Tindak tutur merupakan unsur pragmatik yang melibatkan pembicara dan pendengar atau penulis dan pembaca serta hal yang dibicarakan tentu saja tanpa mengenyampingkan konteks lain yang menyertai pada saat tindak tutur tersebut berlangsung. Dilihat dari sudut penutur, maka bahasa itu berfungsi personal atau pribadi (fungsi emotif). Maksudnya, si penutur menyatakan sikap terhadap apa yang dituturkannya. Si penutur bukan hanya mengungkapkan emosi lewat bahasa, tetapi juga memperlihatkan emosi itu sewaktu menyampaikan tuturannya. Dalam hal ini, pihak si pendengar juga dapat menduga apakah si penutur sedih, marah atau gembira (Chaer, 2004 : 15).

Dilihat dari segi pendengar atau lawan bicara, maka bahasa itu berfungsi direktif, yaitu mengatur tingkah laku pendengar. Dalam hal ini, bahasa itu tidak hanya membuat pendengar melakukan sesuatu, tetapi melakukan kegiatan sesuai dengan yang diinginkan 
oleh si pembicara. Hal ini dapat dilakukan si penutur dengan menggunakan kalimat-kalimat yang menyatakan perintah, himbauan, permintaan, maupun rayuan (Chaer, 2004 : 15-16). Jupri Malino menyatakan bahwa tindak tutur atau tindak ujaran (speech act) mempunyai kedudukan yang sangat penting dalam pragmatik karena tindak Tutur adalah satuan analisisnya (http://juprimalino.blogspot.com/2011/06/tindaktutur-lokusi-ilokusiperkolusi.html)

Penelitian dalam dunia pragmatik tentang tindak tutur telah dilakuakan berbagai pihak, baik dalam bentuk penenlitian akhir studi seperti tesis maupun penelitian-penelitian 'sederhana' yang diterbitkan dalam sebuah jurnal. Misalnya, penelitian Basuki (2007) di Jurnal Mudra terbitan ISI Denpasar. Basuki melakukan studi berjudul "Peranan Tindak Tutur dalam Seni Pertunjukan Ketoprak" yang mengulas tentang (a) deskripsi berbagai bentuk tindak tutur dalam ketoprak, (b) beberapa konteks tuturan, dan (c) fungsi tindak tutur dalam ketoprak.

Dalam lingkup kajian penenlitian yang lebih spesifik dilakukan oleh Yuniarti. Dalam penenlitiannya yang berjudul Kompetensi Tindak. Tutur Direktif Anak Usia Prasekolah (Kajian Kelompok Bermain Anak Cerdas P2PNFI Regional II Semarang), Yuniarti (2010, xi) menemukan bahwa dalam menanggapi atau merespon TTD, anak usia prasekolah melakukannya dalam dua bentuk utama yaitu mengiyakan atau menolak. Dalam mengiyakan atau menyetujui TTD anak melakukannya dalam dua cara yaitu secara verbal dan non verbal. Demikian pula ketika melakukan penolakan terhadap TTD, anak melakukannya secara verbal maupun non verbal. Perkembangan pemahaman anak usia prasekolah terhadap TTD kaitannya dengan kesantunan menunjukkan adanya penggunaan strategi untuk meminimalkan ancaman terhadap muka negatif yaitu melalui penolakan tidak langsung dengan alasan dan penolakan tidak langsung dengan alternatif.

Austin mengemukakan bahwa secara pragmatis setidak-tidaknya ada tiga jenis tindakan yang dapat diwujudkan oleh seorang penutur, yaitu tindak lokusi, tindak ilokusi, dan tindak perlokusi (dalam Cummings, 2010: 9-10). Menunjang pernyataan tersebut, Searle (dalam Trosborg, 1994:14), selanjutnya mengklasifikasi tindak tutur ke dalam lima jenis yaitu: representatives, directives, expressives, commisives dan declaration.

Jenis tindak tutur representatif adalah jenis tindak tutur dimana penutur menginginkan mitra tutur mempercayai ujarannya. Jenis tindak tutur direktif adalah usaha dimana penutur menginginkan mitra tutur melakukan sesuatu seperti yang diujarkannya. Sementara jenis tindak tutur komisif adalah tindak tutur yang mengandung janji bahwa penutur akan melakukan suatu tindakan di masa datang, sementara jenis tindak tutur ekspresif adalah jenis tindak tutur yang digunakan untuk mengungkapkan perasaan atau kondisi psikologis atau apa yang ada di dalam benak penutur yang nantinya berpengaruh pada mitra tutur. Jenis tindak tutur yang terakhir yaitu tindak tutur deklarasi berfungsi untuk menginformasikan kepada mitra tutur atau bahkan kepada publik tentang sesuatu hal dan kemungkinan berpengaruh pada kehidupan.

Dalam penelitian ini, diulas tentang wujud tindak tutur yang dikemuakakan oleh Jhon L. Austin berupa lokusi, ilokusi, dan perlokusi dalam wawancara yang dilakukan oleh wartawan RCTI, Putra Nababan dengan Presiden Portugal, Anibal Antonio Cavaco Silva. 
Dalam usaha untuk mengungkapkan diri mereka, orang-orang tidak hanya menghasilakan tuturan yang mengadung kata-kata dan struktur-struktur gramatikal saja, tetapi mereka juga memperlihatkan tindakan-tindakan melalui tuturan-tuturan itu. Tindakan-tindakan yang dihasilkan lewat tuturan inilah yang disebut tindak tutur (Yule, 2006: 81-82).

Chaer dan Agustina (2004: 49-50) menjelaskan bahwa tindak tutur (speech act) merupakan kemampuan seseorang dalam berbahasa dalam menghadapi situasi tertentu. Tindak tutur ini merupakan gejala individual yang muncul dari pihak penutur dan bersifat psikologis.

Kridalaksana (2001: 171) memberikan pengertian tindak tutur sebagai berikut.

1. perbuatan berbahasa yang dimungkinkan oleh penutur dan diwujudkan sesuai dengan kaidah-kaidah pemakaian-pemakaian unsur-unsur bahasa, 2. perbuatan menghasilkan bunyi bahasa secara berurutan sehingga meghasilkan ujaran yang bermakna, 3. seluruh komponen linguistik dan nonlinguistik yang meliputi suatu perbuatan bahasa yang utuh, yang menyangkut partisispan, bentuk penyampaian amanat, topik, dan konteks amanat itu, 4. pengujaran kalimat untuk menyatakan agar suatu maksud dari pembicara diketahui pendengar.

Berdasarkan pendapat di atas dapat disimpulkan bahwa tindak tutur merupakan suatu tindakan berbahasa yang menekankan fungsi-fungsi bahasa dan pemakaiannya dalam komunikasi. Sebuah percakapan dalam komunikasi tidak hanya dipahami dari kata-katanya, tetapi harus dipahami juga makna yang dikehendaki penuturnya. Peserta harus menggunakan makna kata-kata yang dipadukan dengan konteks tempat kata-kata itu terjadi, sehingga makna yang dikehendaki oleh penutur dapat dicerna dan dipahami.

Contoh:

"Teh ini benar-benar dingin"

Tindak tutur ini bisa ditafsirkan sebagai suatu keluhan. Akan tetapi, apabila diungkapkan dalam keadaan di suatu hari yang panas, ketika penutur diberi segelas es teh oleh pendengar, lalu ia menghirupnya dan menghasilkan tuturan (19). uturan ini mungkin ditafsirkan sebagai suatu penghargaan.

Austin mengemukakan bahwa secara pragmatis setidak-tidaknya ada tiga jenis tindakan yang dapat diwujudkan oleh seorang penutur, yaitu tindak lokusi, tindak ilokusi, dan tindak perlokusi (dalam Cummings, 2010: 9-10).

\section{a. Tindak Lokusi (locutionary act)}

Tindak lokusi adalah tindak tutur untuk menyatakan sesuatu (Leech, 1993: 316). Tuturan ini disebut sebagai The act of saying something. Dalam tindak lokusi, tuturan dilakukan hanya untuk menyatakan sesuatu tanpa ada tendensi atau tujuan yang lain, apalagi untuk memengaruhi lawan tuturnya. Tindak lokusi relatif mudah untuk diindentifikasikan dalam tuturan karena pengidentifikasiannya cenderung dapat dilakukan tanpa menyertakan konteks tuturan yang tercakup dalam situasi tutur (Parker dalam Wijana, 1996:18). Dalam kajian pragmatik, tindak lokusi ini tidak begitu berperan untuk memahami suatu tuturan.

Searle (dalam Nababan, 1987: 18) menyebut tindak lokusi sebagai propositional act, yaitu mengaitkan suatu topik dengan suatu keterangan dalam suatu ungkapan, serupa 
dengan hubungan "pokok" dengan "predikat" atau "topik" dan "penjelasan" dalam sintaksis. Menurut Austin (dalam Cumming, 2007: 9), tindak lokusi kira-kira sama dengan pengujaran kalimat tertentu dengan pengertian dan acuan tertentu, yang sekali lagi kira-kira sama dengan "makna" dalam pengertian tradisional. Tindak lokusi yang merupakan tindak dasar tuturan atau menghasilkan suatu ungkapan linguistik yang bermakna.

Dari uraian di atas dapat disimpulkan bahwa tindak lokusi yaitu tindak melakukan sesuatu; menghasilkan serangkaian bunyi berarti sesuatu. Dalam lokusi ini fungsi ujaran tidak menjadi perhatian.

\section{b. Tindak Ilokusi (illocutionary act)}

Leech (1993: 316) mengatakan tindak ilokusi merupakan tindakan mengatakan sesuatu. Menurut Searle (dalam Nababan, 1987: 18) tindak ilokusi, yaitu pengucapan suatu pernyataan, tawaran, janji, pertanyaan, dan sebagainya. Hal ini erat hubungannya dengan bentuk-bentuk kalimat yang mewujudkan suatu ungkapan.

Austin (dalam Cummings, 2007: 9) mengatakan bahwa tindak ilokusi seperti memberitahu, memerintah, mengingatkan, melaksanakan, dan sebagainya, yakni, ujaranujaran yang memiliki daya (konvensional) tertentu. Yule (2006: 84) menyatakan tindak ilokusi ditampilkan melalui penekanan komunikatif suatu tuturan. Tindak ilokusi merupakan pembentukan tuturan dengan beberapa fungsi di dalam pikiran.

Tindak ilokusi ialah tindak tutur yang tidak hanya berfungsi untuk menginformasikan sesuatu namun juga untuk melakukan sesuatu. Tuturan ini disebut sebagai The act of doing something.

Contoh:

"Saya tidak dapat datang"

Bila diucapkan kepada teman yang baru saja merayakan pesta pernikahannya tidak saja berfungsi untuk menyatakan bahwa dia tidak dapat menghadiri pesta tersebut, tetapi juga berfungsi untuk melakukan sesuatu untuk meminta maaf. Tindak ilokusi sangat sukar dikenali bila tidak memperhatikan terlebih dahulu siapa penutur dan lawan tutur, kapan dan di mana tindak tutur itu terjadi, dan sebagainya.

Searle dalam Leech (1993:164-166) membagi tindak ilokusi ini menjadi lima yaitu asertif, direktif, komisif, ekspresif, dan deklarasi.

1) Tindak asertif merupakan tindak yang menjelaskan apa dan bagaimana sesuatu itu adanya, artinya tindak tutur ini mengikat penuturnya pada kebenaran atas apa yang dituturkannya (seperti menyatakan, mengusulkan, melaporkan).

Contoh: "Chomsky tidak menulis tentang tumbuhan."

2) Tindak komisif ialah tindak tutur yang berfungsi mendorong penutur melakukan sesuatu. Ilokusi ini berfungsi menyenangkan dan kurang bersifat kompetitif karena tidak mengacu pada kepentingan penutur tetapi pada kepentingan lawan tuturnya (seperti menjanjikan, menawarkan, dan sebagainya).

Contoh:

"Saya akan membetulkannya lain kali"

3) Tindak direktif yaitu tindak tutur yang berfungsi mendorong lawan tutur melakukan sesuatu. Pada dasarnya, ilokusi ini bisa memerintah lawan tutur 
melakukan sesuatu tindakan baik verbal maupun nonverbal (seperti memohon, menuntut, memesan, menasihati).

Contoh:

"Dapatkah Anda meminjami saya sebuah pensil?"

4) Tindak ekspresif merupakan tindak tutur yang menyangkut perasaan dan sikap. Tindak tutur ini berfungsi untuk mengekspresikan dan mengungkapkan sikap psikologis penutur terhadap lawan tutur (seperti mengucapkan selamat, memberi maaf, mengecam).

Contoh:

"Sungguh saya minta maaf"

5) Tindak deklaratif ialah tindak tutur yang berfungsi untuk memantapkan atau membenarkan sesuatu tindak tutur yang lain atau tindak tutur sebelumnya. Dengan kata lain, tindak deklaratif ini dilakukan penutur dengan maksud untuk menciptakan hal, status, keadaan yang baru (seperti memutuskan, melarang, mengijinkan).

Contoh:

Hakim: "Kami nyatakan terdakwa bersalah."

Dari uraian di atas dapat dikatakan bahwa pemahaman terhadap tindak ilokusi merupakan bagian sentral untuk memahami tindak tutur.

\section{c. Tindak Perlokusi (perlocutionary act)}

Tindak perlokusi yaitu hasil atau efek yang ditimbulkan oleh ungkapan itu pada pendengar sesuai dengan situasi dan kondisi pengucapan kalimat (Searle dalam Nababan, 1987: 18). Leech (1993: 316) tindak perlokusi merupakan melakukan tindakan dengan mengatakan sesuatu. Austin (dalam Cummings, 2007: 10) mengungkapkan bahwa tindak perlokusi merupakan apa yang kita hasilkan atau capai dengan mengatakan sesuatu, seperti meyakinkan, membujuk, menghalangi.

Yule (2006: 84) mengungkapkan bahwa tindak perlokusi merupakan akibat dari tuturan yang memiliki fungsi. Tuturan ini disebut sebagai The act of affecting someone. Sebuah tuturan yang diutarakan oleh seseorang seringkali mempunyai daya pengaruh (perlocutionary force) atau efek bagi yang mendengarnya. Efek atau daya pengaruh ini dapat secara sengaja atau tidak sengaja dikreasikan oleh penuturnya. Tindak tutur yang pengutaraannya dimaksudkan untuk mempengaruhi lawan tutur disebut dengan perlokusi. Tindak perlokusi ini biasa ditemui pada wacana iklan. Sebab wacana iklan meskipun secara sepintas merupakan berita tetapi bila diamati lebih jauh daya ilokusi dan perlokusinya sangat besar. Contoh:

"Saya baru saja membuat kopi."

\begin{tabular}{|l|l|l|}
\hline \multicolumn{1}{|c|}{ Lokusi } & \multicolumn{1}{|c|}{ Ilokusi } & \multicolumn{1}{|c|}{ Perlokusi } \\
\hline $\begin{array}{l}\text { "Saya baru saja membuat } \\
\text { kopi." }\end{array}$ & memberitahu & $\begin{array}{l}\text { Agar lawan tutur tidak membuatkan } \\
\text { kopi lagi }\end{array}$ \\
\cline { 2 - 4 } & menawarkan & $\begin{array}{l}\text { Agar lawan tutur tertarik untuk } \\
\text { bergabung ikut minum kopi }\end{array}$ \\
\hline
\end{tabular}




\section{METODE PENELITIAN}

Data yang diulas dan dianalisis dalam penelitian ini di lakukan dengan analisis deskriptif kualitati, hanya mennggambarkan secara verbal mengenai temuan yang diperoleh. Dalam mengakji data penelitian, ada beberapa tahapan yang dilalui, yakni penyediaan data atau pengumulan data, pengklasifikasian atau pengelompokan data, kemudian tahap analisis data. Dalam pengumpulan data, penenliti menggunakan teknik simak, rekam dan catat. Sumber data dalam penenlitian ini diperoleh dari petikan wawancara ekkklusive antara wartawan RCTI, Putra Nababan dengan Presiden Portugal, Antonio Cavaco Silva di Istana Kepresidenan Portugal.

Sumber pijakan teori yang digunakan dalam penelitian ini adalah teori yang dikemukakan oleh Austin yang mengemukakan bahwa secara pragmatis setidak-tidaknya ada tiga jenis tindakan yang dapat diwujudkan oleh seorang penutur, yaitu tindak lokusi, tindak ilokusi, dan tindak perlokusi (dalam Cummings, 2010: 9-10). Teori lain yang menunjang dan digunakan dalam penelitian ini adalah Searle dalam Leech (1993:164-166) membagi tindak ilokusi ini menjadi lima yaitu asertif, direktif, komisif, ekspresif, dan deklarasi.

Dalam pembahasan peneliti menggunakan tanda WN yang berarti wawancara nomor yang diikuti nomor urut wawancara sesuai dengan data transkrip yang terlampir, misalnya untuk menyatakan tuturan yang berada pada hasil wawancara nomor 1, penenliti menyingkat (WN 1).

\section{HASIL PENELITIAN DAN PEMBAHASAN}

Dalam uraian pembahasan penelitian ini, peneliti mengulas data yang telah ditranskrip dalam bentuk tulisan (dalam bentuk video terlampir). Adapun pembahasannya diulas dengan menjelaskan konteks yang menyertai ketika peristiwa tutur berupa wawancara ini terjadi. Berikut pembahasan dan temuan perwujudan tindak tutur yang terdapat dalam wawancara wartawan RCTI, Putra Nababan dengan Presiden Portugal, Antonio Cavaco Silva.

\section{a. Ilokusi}

Wujud tindak tutur ilokusi terdapat dalam beberapa data, diantaranya sebagai berikut.

\begin{tabular}{|c|l|l|}
\hline \multirow{3}{*}{2} & Wartawan & $\begin{array}{l}\text { Terima kasih telah menerima kami di sini. Saya benar-benar } \\
\text { menikmati masyarakatnya, situs sejarah, makanan Portugal, } \\
\text { dan anggurnya. Indah sekali! }\end{array}$ \\
\cline { 2 - 4 } & Presiden & $\begin{array}{l}\text { Masyarakat Portugis adalah masyarakat yang bersahabat dan } \\
\text { mereka selalu senang menyambut tamu dari luar. Kita ini } \\
\text { negeri turis, setiap tahun kita menerima 14 juta turis. Mereka } \\
\text { tertarik dengan cuaca yang baik dan keramahan } \\
\text { masyarakatnya. }\end{array}$ \\
\hline \multirow{3}{*}{3} & Wartawan & $\begin{array}{l}\text { 500 tahun yang lalu pimpinan Portugis datang ke Indonesia } \\
\text { dan setelah itu, Andalah yang pertama. Apakah anda } \\
\text { gembira? }\end{array}$ \\
\hline & Presiden & Dalam beberapa cara, ini masalah perasaan. Tidak hanya \\
\hline
\end{tabular}




\begin{tabular}{|c|c|c|}
\hline & & $\begin{array}{l}\text { gembira, tapi perasaan senang mengetahui kita banyak } \\
\text { persamaan secara historis. Persamaan budaya, persamaan } \\
\text { kata-kata. Kami dipengaruhi oleh nusantara dan sebaliknya } \\
\text { kami juga mempengaruhi masyarakat nusantara di abad 16, } \\
\text { 17, dan 18. Hubungan dia antara dua masyarakat cukup } \\
\text { bersahabat. }\end{array}$ \\
\hline \multirow[b]{2}{*}{4} & Wartawan & $\begin{array}{l}\text { Seperti yang anda ketahui, kedua negara tidak punya } \\
\text { pengalaman yang panjang dalam berhubungan baik. } \\
\text { Bagaimana anda melihat masa depan hubungan kedua } \\
\text { negara? }\end{array}$ \\
\hline & Presiden & $\begin{array}{l}\text { Optimistik. Ketidakcocokan Indonesia-Portugal hanya soal } \\
\text { Timor Timur. Sebelum itu, bahkan presiden pertama } \\
\text { Indonesia sudah mengunjungi Potugal. Dan sekarang, kedua } \\
\text { negara bekerja sama untuk mencapai hasil yang terbaik untuk } \\
\text { masyarakat Timor Timur. Saya sendiri akan berada bersama } \\
\text { Presiden Indonesia dalam pelantikan Presiden Timor Timur } \\
\text { yang baru. Saya piker kita punya banyak yang bisa dilakukan } \\
\text { pada masa mendatang, terutama membangun hubungan } \\
\text { ekonomi. Itulah mengapa delegasi ekonomi penting ikut } \\
\text { bersama saya. Saya pribadi akan terlibat langsung dalam } \\
\text { forum ekonomi dimana pengusaha portugis dan Indonesia } \\
\text { saling berhubungan. Kami ingin Indonesia mengetahui } \\
\text { potensi Portugal lebih baik lagi. }\end{array}$ \\
\hline \multirow[b]{2}{*}{5} & Wartawan & $\begin{array}{l}\text { Jika kita kembali ke masa lalu. Menurut anda, apa yang } \\
\text { sebenarnya terjadi dengan hubungan Indonesia-Portugal } \\
\text { setelah Timor Timur menjadi bagian Indonesia di tahun } \\
\text { 1975? }\end{array}$ \\
\hline & Presiden & $\begin{array}{l}\text { Portugal harus mempertahankan kemungkinan masyarakat } \\
\text { Timor Timur untuk menentukan masa depannya. Itulah } \\
\text { sebabnya mengapa kami mempertanyakannya ke PBB. Di } \\
\text { bawah sekjen PBB saat itu, kita membangun negosiasi antara } \\
\text { perwakilan Portugal dan Indonesia. Kita tahu negosiasinya } \\
\text { sangat alot. Kami tidak pernah bisa menerima } \\
\text { pengambilalihan Timor Timur oleh Indonesia yang melawan } \\
\text { kehendak masyarakat Timor Timur. Itu harus diputuskan } \\
\text { masyarakat Timor Timur sendiri. }\end{array}$ \\
\hline \multirow[b]{2}{*}{6} & Wartawan & Meskipun tahun 1975 telah diadakan referendum? \\
\hline & Presiden & $\begin{array}{l}\text { Tapi idenya adalah membuat referendum yang dikontrol } \\
\text { PBB. Waktu itu juga ada undangan dari ketu parlemen } \\
\text { Indonesia agar parlemen Portugal setelah itu mengunjungi } \\
\text { Timor Timur. Tapi waktu itu ada beberapa kesulitan. } \\
\text { Sehingga Portugal harus berpihak kepada keinginan } \\
\text { pimpinan dan masyarakat Timor Timur. Dan akhirnya }\end{array}$ \\
\hline
\end{tabular}




\begin{tabular}{|c|c|c|}
\hline & & semuanya berujung dengan kebahagiaan. \\
\hline \multirow[b]{2}{*}{7} & Wartawan & $\begin{array}{l}\text { Bicara tentang akhir yang manis. Kita mengakhiri krisis } \\
\text { Timor Timur dengan sangat baik melalui referendum tahun } \\
\text { 1999. Tapi kenapa Jaksa Agung Portugal menuntut Presiden } \\
\text { kedua Indonesia ke Mahkamah Internasional di Den Haag } \\
\text { Belanda? }\end{array}$ \\
\hline & Presiden & $\begin{array}{l}\text { Saat itu Portugal harus menggunakan segala cara agar } \\
\text { masyarakat Timor Timur mendapatkan otomi dan memilih } \\
\text { masa depannya sendiri, bahkan kemerdekaan. Jadi target } \\
\text { utama kami adalah mencari perhatian dari masyarakat } \\
\text { Internasional. Sebagai bagian dari Uni Eropa, kita mendapat } \\
\text { dukungan dari teman-teman kami dan setelah itu kami } \\
\text { menyerahkannya ke PBB. Jadi kami menginformasikan } \\
\text { kepada komunitas Internasional bahwa ada masalah yang } \\
\text { harus dipecahkan. Portugis berada di Timor Timur selama } \\
\text { berabad-abad. Terjadi perang saudara di Portugal setelah } \\
\text { revolusi tahun 1974, lalu ada invasi ke Timor Timur oleh } \\
\text { tentara Indonesia dan itu tidak sesuai dengan keinginan } \\
\text { rakyat. Portugal harus bereaksi dengan membela keinginan } \\
\text { rakyat. Dan wajar sekali jika saat itu ada ketegangan di antara } \\
\text { kedua pemerintahan, bukan rakyatnya. Karena persahabatan } \\
\text { kedua masyarakat tidak tersentuh. }\end{array}$ \\
\hline \multirow[b]{2}{*}{8} & Wartawan & $\begin{array}{l}\text { Meskipun bagi sebagian masyarakat Indonesia, langkah } \\
\text { Portugal menuntut presiden keduanya bukanlah sebuah } \\
\text { tanda persahabatan? }\end{array}$ \\
\hline & Presiden & $\begin{array}{l}\text { Itulah yang menjadi alasan saya pribadi mau datang ke sana } \\
\text { (Indonesia). Saya ingin menyampaikan bahwa Portugal dan } \\
\text { Indonesia mempunyai masa lalu yang sama sehingga kita } \\
\text { harus menghargainya. Berabad-abad lalu kita sudah saling } \\
\text { berkomunikasi dan berdagang. Portugal itu seperti duta besar } \\
\text { Eropa di nusantara, menjelaskan tentang Eropa kepada } \\
\text { masyarakat Indonesia. Tapi kami juga membawa dari } \\
\text { Indonesia pandangan dan cara hidup baru untuk masyarakat } \\
\text { Eropa. Jadi kita harus mendapat keuntungan dari kesamaan } \\
\text { masa lalu ini. Masa lalu yang penuh persahabatan, hubungan } \\
\text { perdagangan dan kerja sama. Mari kita lupakan perselisihan } \\
\text { tentang Timor Timur dan setelah menjadi negara dekomratis, } \\
\text { kita memiliki tantangan baru. Mari kita mencari keuntungan } \\
\text { dari masa depan dengan memperkuat kerja sama di antara } \\
\text { kedua negara kita. }\end{array}$ \\
\hline 9 & Wartawan & $\begin{array}{l}\text { Untuk menambah semangat dan sikap optimis Anda, saya } \\
\text { mengetahui banyak kata dalam bahasa Indonesia asalnya dari }\end{array}$ \\
\hline
\end{tabular}




\begin{tabular}{|c|l|l|}
\hline \multirow{2}{*}{} & $\begin{array}{l}\text { bahasa Portugis. Kalau saya boleh, Bapak Presiden, saya akan } \\
\text { sebutkan beberapa kata dalam bahasa Indonesia dan saya } \\
\text { meminta anda untuk menyebutkannya dalam bahasa }\end{array}$ \\
& $\begin{array}{l}\text { Portugis, sehingga pemirsa Indonesia dapat mendengar dan } \\
\text { melihat bahwa kita memang memiliki persamaan. Apakah } \\
\text { anda siap Bapak Presiden? }\end{array}$ \\
\hline \multirow{2}{*}{10} & Wartawan & Bangku \\
\cline { 2 - 3 } & Presiden & banco \\
\hline \multirow{2}{*}{11} & Wartawan & Bahasa Portugis bangku juga ya? \\
\cline { 2 - 3 } & Presiden & Iya bangku juga. \\
\hline
\end{tabular}

Berdasarkan data yang terdapat di atas, tindak ilokusi terdapat pada WN 2 sampai dengan WN 11. Berikut akan dijabarkan secara rinci dengan memilah tindak ilokusi tersebut dengan mengacu pada teori yang dikemukakan oleh Searle dalam Leech (1993:164166) yang membagi tindak ilokusi ini menjadi lima yaitu asertif, direktif, komisif, ekspresif, dan deklarasi.

\section{Tindak asertif}

Tindak ilokusi berjenis asertif terdapat pada tuturan WN 2. Tuturan yang diungkapkan oleh wartawan bahwa "500 tahun yang lalu pimpinan Portugis datang ke Indonesia dan setelah itu, Andalah yang pertama”. Hal ini memang sesuai dengan kenyataan yang ada dan dapat dipertanggungjawabkan kebenarannya oleh penutur. Dan dalam hal ini, penutur tidak hanya memberitahukan kepada lawan tutur tentang sebuah sejarah tetapi mempertegas kepada lawan tutur tentang sebuah kemajuan hubungan yang terjalin antara Indonesia-Portugal.

Begitu juga dengan yang terdapat dalam WN 6, penutur menanyakan “Meskipun tahun 1975 telah diadakan referendum?", itu artinya bahwa penutur memang mengetahui bahwa tahun 1975 telah diadakan referendum. Berbeda halnya jika penutur bertanya "Apakah tahun 1975 telah diadakan referendum?". Dengan adanya kata "meskipun" dan "telah" penutur ingin meminta penjelasan langsung secara tegas tidak hanya bermaksud sekedar bertanya kepada lawan tutur.

Tidak jauh berbeda dengan kasus yang terdapat pada WN 6, pada WN 7, penutur menanyakan "Kita mengakhiri krisis Timor Timur dengan sangat baik melalui referendum tahun 1999. Tapi kenapa Jaksa Agung Portugal menuntut Presiden kedua Indonesia ke Mahkamah Internasional di Den Haag Belanda?” Pada pertanyaan tersebut penutur tidak hanya menanyakan tragedi tersebut seperti apa, tetapi meminta penjelasan lebih mendalam dari tokoh yang memang mengetahui banyak hal tentang kasusu tersebut.

Data tersebut tentunya sejalan dengan teori yang dikemukakan oleh Searle dalam Leech (1993:164) yang menyatakan bahwa tindak asertif merupakan tindak yang menjelaskan apa dan bagaimana sesuatu itu adanya, artinya tindak tutur ini mengikat penuturnya pada kebenaran atas apa yang dituturkannya (seperti menyatakan, mengusulkan, melaporkan). 


\section{Tindak komisif}

Tidak ilokusi berjenis komisif terefleksi dalam tuturan Presiden yang menyatakan bahwa "Itulah yang menjadi alasan saya pribadi mau datang ke sana (Indonesia). Saya ingin menyampaikan bahwa Portugal dan Indonesia mempunyai masa lalu yang sama sehingga kita harus menghargainya." (WN 8). Dalam tuturan tersebut, tidak hanya bermaksud menginformasikan kepada lawan tutur, tetapi berisi janji bahwa Presiden Portugal akan dating sendiri ke Indonesia tanpa berwakil.

\section{Tindak direktif}

Pada WN 9, terdapat ujaran penutur yang menyatakan "Kalau saya boleh, Bapak Presiden, saya akan sebutkan beberapa kata dalam bahasa Indonesia dan saya meminta anda untuk menyebutkannya dalam bahasa Portugis, sehingga pemirsa Indonesia dapat mendengar dan melihat bahwa kita memang memiliki persamaan. Apakah anda siap Bapak Presiden?”. Ujaran tersebut tidak hanya menanyakan siap atau tidaknya lawan tutur menjawab pertanyaan, tetapi penutur meminta lawan tutur untuk melaksanakan dan mengikuti instruksi yang akan di minta penutur.

\section{Tindak ekspresif}

Tindak ilokusi yang bersifat ekspresif terlihat pada WN 3. Penutur menanyakan tentang perasaan lawan tutur terkait dengan statusnya sebagai presiden kedua yang datang ke Indonesia setelah 500 tahun silam. Pertanyaan penutur tersebut kemudian dijawab oleh lawan tutur "dalam beberapa cara, ini masalah perasaan. Tidak hanya gembira, tapi perasaan senang mengetahui kita banyak persamaan secara historis...." (WN 3). Hal tersebut diungkapkan secara ekspresif, dengan mimik wajah senang dan tertawa kecil.

Dari tuturan dan bahasa tubuh yang diperlihatkan oleh lawan tutur tersebut dapat diidentifikasikan bahwa WN 3 merupakan tindak ilokusi jenis ekspresif. Seperti yang dikemukakan oleh Searle dalam Leech (1993:164-166), tindak ekspresif merupakan tindak tutur yang menyangkut perasaan dan sikap. Tindak tutur ini berfungsi untuk mengekspresikan dan mengungkapkan sikap psikologis penutur terhadap lawan tutur.

\section{Tindak deklaratif}

Tindak tutur ini berfungsi untuk memantapkan atau membenarkan sesuatu tindak tutur yang lain atau tindak tutur sebelumnya. Sejalan dengan teori tersebut, pada WN 10 dan 11 merupakan wujud tindak ilokusi berjenis deklaratif. Pada WN 10 wartawan menanyakan tentang bahasa Portugis "bangku", daan dijawab oleh Presiden "banco", seolah tidak percaya dengan kemiripan tersebut, wartawan kembali mempertegas dengan menanyakan "Bahasa Portugis bangku juga ya?" (WN 11). Pada WN 11, tidak hanya bermaksud bertanya karena tidak mendengar atau tidak jelas, tetapi untuk meminta penegasan kembali.

\section{b. Perlokusi}

Data yang berhubungan dengan tindak perlokusi terdapat dalam WN 16 dan 18 berikut ini. 


\begin{tabular}{|l|l|l|}
\hline \multirow{2}{*}{16} & Wartawan & Yang kita lakukan sudah lumayan ini. Meja \\
\cline { 2 - 3 } & Presiden & Mesa. Mesa. Mesa. \\
\hline \multirow{2}{*}{18} & Wartawan & Sepatu \\
\cline { 2 - 3 } & Presiden & Sepato \\
\hline
\end{tabular}

Telah dinyatakan sebelumnya bahwa perlokusi merupakan tindak tutur yang pengutaraannya dimaksudkan untuk mempengaruhi lawan tutur atau efek yang ditimbulka dari tuturan. Dari data wawancara, tindak perlokusi hanya terdapat pada beberapa bagian akhir peristiwa tutur, yakni pada WN 16 dan 18. Pada WN 16, penutur menanyakan asal kata "meja" dalam bahasa Potugis yang kemudian dijawab "mesa" oleh lawan tutur. konteks yang menyertai pada saat peristiwa ini terjadi adalah pada saat lawan tutur menjawab "mesa", penutur terdiam sejenak. Dari mimik wajah yang ditunjukkan penutur memperlihatan kebingungan. Oleh sebab itu lawan tutur menjawab "mesa" sambil memukul-mukul secara perlahan meja yang berada di dekatnya.

WN 18 pun demikian. Konteks yang terjadi pada saat penutur menanyakan asal kata "sepatu" dalam bahasa Portugis yang kemudian dijawab "sepato" oleh lawan tutur. Penutur kemudian menanyakan kembali dengan berkata "ini sama?", lawan tutur menjawab dengan sedikit mengangkat kaki yang bermaksud menunjukkan benda yang disebut "sepatu" adalah yang sedang ia kenakan di kakinya saat itu.

\section{SIMPULAN}

Berdasarkan pembahasan di atas wujud tindak tutur berupa lokusi tidak terdapat dalam wawancara wartawan RCTI Putra Nababan dengan Presiden Portugal, Antonio Cavaco Silva. Sebab semua tuturan yang terdapat dalam wawancara tersebut mengandung tendensi tertentu seperti mempertegas, menanyakan, atau meyakinkan.

Dari data yang ada lebih banyak mengandung tindak ilokusi dengan semua jenisnya. Tindak ilokusi berjenis asertif sebanyak tiga, tindak komisif sebanyak satu, tindak direktif juga satu, tindak ekspresif sebanyak satu, dan tindak deklaratif sebanyak dua.

Adapun tindak perlokusi dalam data, tercatat hanya dua. Untuk lebih jelasnya mengenai efek yang ditimbulkan oleh tuturan penutur dapat dicermati dalam lampiran video.

\section{DAFTAR PUSTAKA}

Abdul Chaer dan Leonie Agustina. 2004. Sosiolinguistik: Perkenalan Awal. Jakarta: Rineka Citra.

Agus Rinto Basuki. 2007. Peranan Tindak. Tutur dalam Seni Pertunjukan Ketoprak. Denpasar: Jurnal Mudra edisi September 2007.

Cummings, Louise. 2007. Pragmatik: Sebuah Perspektif Multidisipliner. Yogyakarta: Pustaka Pelajar.

Cummings, Louise. 2010. Pragmatik Klinis. Yogyakarta: Pustaka Pelajar.

Harimurti Kridalaksana. 2001. Kamus Linguistik. Jakarta: Gramedia. 
ISSN (Online): 2621-0851

Volume 1, Nomor 1, Mei 2018

I Dewa Putu Wijana. 1996. Dasar-dasar Pragmatik. Yogyakarta: Andi Offset.

Leech, Georfrey. 1993. Prinsip-prinsip Pragmatik. Jakarta: Universitas Indonesia.

Malino, Jupri. 2011. Tindak Tutur, Lokusi, Ilokusi, dan Perlokusi. (http://juprimalino.blogspot.com/2011/06/tindaktutur-lokusi-ilokusiperkolusi.html)

Trosborg, Anna. 1994. Interlanguage Pragmatics: Request, Complaints, Apologies. Berlin: Mouton de Gruyter.

Yule, George. 2006. Pragmatik. Yogyakarta: Pustaka Pelajar.

Yuniarti. 2010. Kompetensi Tindak Tutur Direktif Anak Usia Prasekolah (Kajian pada Kelompok Bermain Anak Cerdas P2PNFI Regional II Semarang). Tesis. Semarang: PPS Universitas Diponegoro. 